Review scientific article Received 11.07.2018. Approved 06.11.2018.

\title{
MEDIA EDUCATION AS COUNTERPOINT TO THE DEVASTATION OF PUBLIC INFORMATION IN SERBIA
}

In modern information and IT society, creativity is elevated to a pedestal as a condition for market success, but also survival. In other words, in post-industrial production, or the entire economy, and certainly media companies, which of course operate according to market principles and are based on information, creativity is the most wanted commodity.

In the modern knowledge society, there has been a strong affirmation of the phenomenon of cultural, that is, creative industries that have great importance for the economic, social, political and general development of society. At the same time, changes in the economic, technological and cultural spheres have strongly influenced changes in the media, as an important creative industry. This means that media products (information, videos, pics) and the media are industry, not only because of the rating criteria which dictate the direction of business but also because it is about mass production and consumers. Creativity is an important strategic resource for increasing competitiveness in a knowledge-based economy. However, media policy does not encourage the systematic promotion of creativity. Consumerist entertainment industry suppresses and marginalizes authentic, creative cultural practices, replacing them with pseudo-cultural contests.

The integration of theoretical knowledge and education into the Serbian media sphere is practically at the zero points with recurrences that seriously undermine the overall development, application of knowledge, modern technological achievements, and the affirmation of democracy and freedom as the basic precondition for the overall prosperity of society.

Keywords: Creativity, Competition, Media Education, Media Industry, Public Information.

* Faculty of Culture and Media, Megatrend University, Belgrade, Serbia; ntorlak@megatrend.edu.rs

** FFaculty of Culture and Media, Megatrend University, Belgrade, Serbia; mjokic@megatrend.edu.rs 


\section{Introduction}

In the modern informatical and information society, creativity has been raised to a pedestal. It has become a condition for market success, but also survival. In other words, in post-industrial production, that is, in the entire economy, and certainly in media companies, which of course operate according to market principles and are based on information, creativity is the most wanted commodity.

In spite of this, the notion of creativity is not easy to define, because there are still doubts about what we mean by that term. In order to better understand creativity, perhaps we should embark on a chronological and etymological path, that is, we should put it into certain social, economic and political contexts, and thus we return a couple of decades back in time. In short, we should revise the differences between industrial and post-industrial societies. ${ }^{1}$

In an industrial society, a relatively narrow circle of people "produced" ideas, new concepts, while most were in charge of realization process, making specific products out of these ideas. Then the design team of about ten people created the look of cars, buildings, machines, magazines, after which thousands of workers turned these conceptual solutions into mass-produced products.

In post-industrial society, the picture is completely different. Because of the high automation production that technological progress has brought us, production lines have fewer workers than ever, while the number of employees in nonproductive activities has increased enormously. Millions of designers, artists, engineers create new products, and perfect old ones, which are then ferociously bought by the consumer society, of course "with the unselfish help" of selling and advertising marketing magicians. By transforming the industrial society into a post-industrial society, the majority of employees no longer create concrete, tangible products - but deals with different forms of information manipulation. ${ }^{2}$

\section{Creativity as Human Capital}

Etymologically the word is derived from the Latin word "creatus", which literally means "the one that grew". Creativity should be distinguished from innovation. The first term is usually used to create new ideas or approaches, while innovation is the process of creating and applying creative ideas. Innovation "starts with creative ideas,"... "creativity by an individual or group is the starting point for innovation". 3

Castells, M. (2000): Informacijsko doba: Ekonomija, društvo i kultura, Svezak I: Uspon umreženog društva; (2002): Svezak II: Moć identiteta; (2003): Svezak III: Kraj tisućljeća. Zagreb: Golden marketing.

2 Jandrić, P. (2015): Digitalno učenje. Zagreb: Školske novine i Tehničko veleučilište u Zagrebu.

3 Amabile, T. M., R. Conti, H. Coon, J. Lazenby, and M. Herron. (1996): “Assessing the Work Environment for Creativity”. Academy of Management Journal 39, no. 5 (October 1996): 
Although neither the ancient Greeks nor the Romans had words that would be adequate to today's term of creativity, we describe their creative work using the word creativity. In the Christian period, "creatio" is the word that describes God's "creation from nothingness." After the 18th century and the Age of Enlightenment, the concept of creativity appears increasingly in the theory of art, but it also connects to the concept of imagination. ${ }^{4}$

There are more than 60 different definitions of creativity in psychological literature. The most commonly mentioned is: creativity is the ability to produce artwork that is not only new (i.e. original, unexpected) but also useful. ${ }^{5}$ This definition has its own shortcomings (which we will not discuss on this occasion), nor shall we deal with problems like: how can one learn to be creative? Traditional pedagogy has instruments that can value knowledge, but not an answer to the question of how to evaluate and recognize the creativity of students.

Since knowledge and creativity today are the most valuable and most soughtafter goods in contemporary society, the concept of human capital has developed, which can be described as a set of different knowledge, skills and creative potentials of a person. Already the description itself leads us to individuality. Such creativity is aimed at gaining advantage over a colleague, making them compete with one another, focused on particularity. This in educational institutions implies excellent success, since today's schools face a large number of students with excellent success, and thus the particularity is called into question.

Post-industrial production based on information raises creativity on a pedestal - which defines an individual through human capital - which develops through upbringing and education - leading to strong individualism - which leads to Darwinism. We can call a person who defines himself through human capital with the Latin name homo economicus, because its whole existence is defined by the laws of supply and demand. ${ }^{6}$

\section{Education for Creativity}

In the digital world, however, knowledge production and creativity are linked to openness and sharing. Typical examples include social networks that rest on users who produce and share content - information, images, videos... In the 1990s, the emergence of Web 2 has encouraged the creation of new forms of knowledge and new forms of creativity. In the context of knowledge creation,

1154-1184.

4 Milivojević, T. (2011): Psihologija stvaralštva, Beograd, Megatrend univerzitet.

Baron Robert (1995): Behaviour in Organizations, Prentice Hall, Inc.

Peters, M. A. \& Heraud. R. (2015): Toward A Political Theory Of Social Innovation:

Collective intelligence and the co-creation of social goods. Journal of Self-Governance and

Management Economics, 3(3), 7-23. 
Howard Rheingold introduces the concept of the wisdom of the crowd, which delineates the intellectual efforts of a lonely creative individual with the co-operation of a large number of people.

It recognizes that complex social problems require the collaboration of a large number of involved citizens, especially in times of crisis. ${ }^{8}$ This also means a transformation in which education plays a major role primarily in encouraging individual talent and simultaneous preparation of an individual for acting in competitive environments.

Modern science and industry are less reliant on a talented individual, and more on the work of large teams. This trend is present more or less in all areas of human activity. Modern designers, developers, scientists and artists generally work in large teams, in which they gained thanks to their previous individual knowledge, skills and successes.

Great Britain was the first country to politically focus on creative industries (to use the term within the state cultural policy) and the establishment of the Creative Industry Task Force within the Department of Culture, Media and Sport, in 1997. It defines creative industries as those industries that originate from individual creativity, skills and talent, and have the potential to create wealth and jobs through the generation and exploitation of intellectual property.

This definition is the most widespread and accepted definition of creative industries, especially in Europe, and includes advertising, architecture, art and antiques, crafts, design, fashion design, film, video, photography, computer games, music, performing and visual arts, publishing, television and radio.

Creative industries are largely the privilege of developed countries, as they require a high degree of innovation, expertise and use of the latest technologies.

\section{Creativity and Education as a Strategic Resource for Increasing Competitiveness}

In the modern knowledge society, there has been a strong affirmation of the phenomenon of cultural, that is, creative industries that have great importance for the economic, social, political and general development of society. At the same time, changes in the economic, technological and cultural spheres have strongly influenced the changes in the media, as an important creative industry. This means that media products (information, videos, pics) and the media is industry, not only because of the rating criteria, which dictate the direction of business, but also because it is done like in every mass production consumer industry.

7 Rheingold, H. (1995): The Virtual Community: Homesteading on the Electronic Frontier. Cambridge, MA: MIT Press; Rheingold, H. \& Jandrić, P. (2015): Learning in the age of mind amplification. Knowledge Cultures, 3(5), 149-164.

$8 \quad$ Peters, M. A. \& Heraud. R. (2015). 
Creativity is an important strategic resource for increasing competitiveness in a knowledge-based economy. However, media policy does not encourage systematic promotion of creativity. Consumer entertainment industry suppresses and marginalizes authentic, creative cultural practices, replacing them with pseudo-cultural content.

Solving the complex problem can not start unless we clarify the significance and essence of the content of concepts, which are interpreted in theoretical and practical terms too freely and arbitrarily which in the result leads to terminological confusion and a complete misunderstanding of media education concept, media literacy and media education.

The listed areas, mixed in rhetorical presentation and inadequate understanding of which scope falls under these set of concepts, lead to permanent confusion in Serbian discussion forums. This is resolved by insisting that media education, media literacy and education in media is implemented out of ignorance, rejected and placed behind the scenes and lodges of the creators of the media, and in general the whole cultural policy. Mirko and Nevena Miletić in "Communicative lexicon" define media education as "the use of media in the institutionalized educational process of the so - called „educational technologies, didactic tools and teaching aids or as the first conceiving didactic sense condition, a completely new educational process similar to creation of the informational society." The same authors interpret media literacy as "a metaphorical name for a set of individual developmental abilities, critical reception and evaluation of media content, the skills of using and managing the media and their creative use in the work process in everyday life" .

Media literacy is a precondition of the so-called functional literacy, without which it is not possible to satisfy the individual and group needs of people in contemporary society. Media literacy, according to Tomislav Sikic (Hrvatski obrazovni portal Zbornica), develops various skills: technical (ability to access media), critical (understanding, and ability to interpret and critically evaluate media content), and practical (ability to create media messages).

This makes it possible, according to Sikić, that the media is understood and in a good way, without stereotypes, accepted in a society that they carefully and critically observe. Media education, knowledge, values or cultural patterns are acquired and adopted by people's exposure to mass media and the use of the Internet. All this towards Mirko and Nevena Miletić represents the opposite of formal, i.e. classic preschool and primary, secondary and higher education. Education and knowledge, established as a key human resource of the modern age, implicitly require intellectual capital integration into practice as the most dominant driving force for a quality and comprehensive creation of a knowledge society.

Miletić, M., Miletić, N., (2012), Komunikološki leksikon, Beograd: Megatrend univerzitet. 


\section{Media and Media Practice in Serbia}

Integrating theoretical knowledge and education into the Serbian media sphere, regardless of whether it is printed, electronic or mass media is practically at the zero point with recurrences that seriously undermine the overall development, the application of knowledge, modern technological achievements, the affirmation of democracy and freedom as a basic precondition for the overall prosperity of the society.

Media practice in Serbia is reflected in reintegration, retrograde and numerous side effects. These areas not only permanently devastated, but are placed on margins or below it. The powers of political elites, the direct and open synthesis of ignorance with many different interest groups, create unimaginable consequences in all social areas. The lack of principle elements recognition in media messages - mostly wrongly decoded - creates and shapes public opinion with incredible explosiveness and intensity, and the entire society portrays the degree of mediocrity and ubiquitous superficiality to the level of mediocrity. The media system in Serbia is far from the first transition phase, starting from the essential changes in the economic model of business - the constant wandering between state interventionism and non-transparent, legally suspicious private ownership structures, leading to general confusion and open issues in terms of freedom from direct mixing of political structures into business and editorial policy downgraded to support of one, and complete elimination, and economic obstruction of all others opposed to the current government. Especially after the fall of Slobodan Milosevic's regime in 2000, there are constant debates about the drastic, dual process taking place - economic decline and collapse of credibility, integrity and autonomy of media outlets. It all comes down to the repeated diagnoses that Serbia within the European framework belongs to the group of countries with the lowest level of critical media consciousness. In fact, the whole concept of restructuring is more a formal adaptation to the legal provisions of EU members than the internal need to approach this issue in a way that would contribute significantly to the improvement of general media literacy, media education and education in media. In this context, it is important to analyze "whether we need media literacy" and why we have built models that reject a modern approach to media culture structured through the synthesis of two key aspects: media education and the way media education is achieved. The society as a whole directs the concept of media literacy to rhetorical actualization on freedom of media expression, polemics about media strategies, legal regulations, which treat the freedom of the press, but not the essential values that are manifested in the daily activities of media conglomerates. This directly affects, but also creates the life of each individual in the community. Wide range, the cohesion force, which would base the media scene on different, high-quality and theoretically applicable and generally accepted models, in these deeply polar- 
ized discussions almost does not exist. The value of the Declaration of Media Education (1982) has remained founded on the starting point and basic idea, well purified through practice - communication rights derived from basic human rights. Nevertheless, the Serbian media scene and reality is characterized by suppression from the focus of the public to issues of general understanding of the relationship between creators and producers of information and their users. In economic, sociological, cultural, moral, aesthetic, and principle terms, this unity of opposites - the media and users - form a whole that continuously represents a permanent paradox, blurring the basic media postulates, although at first glance it might be noted that this possibility is out of the question.

\section{Two Minor Case Studies}

An internal case study, conducted in 2010, emerged more as a rhetorical need for top managers in the newspaper company "Vecernje Novosti" highly positioned on the Serbian press market, illustrates the level of education of journalists who daily addressed their potential users. The fact that in highcirculation daily newspapers (for Serbian circumstances, with 260 employees) only $20 \%$ of all employees in the system had a high professional education is frustrating and quite discouraging. When asked "how many journalists, editors and other members of the editorial team lack the theoretical knowledge and whether the practice alone can replace that gap", ninety percent of the respondents answered that knowledge of theoretical forms is not necessary for quality work in the media sphere. Another data from the survey says: the majority of the editorial staff started to work in media outlets by graduating from secondary schools, which qualified them as high school graduates with diplomas for car painters, electricians, machine locksmiths, technicians. Lastly, the Association of Journalists of Serbia announced a few years ago that more than half percent of employees in media organizations do not possess a diploma in higher educa$\operatorname{tion}^{10}$. In the synthesis of ignorance occurred the logical and natural devastation of messages emitted in enormous quantities. Without any profound selectivity and good expert judgment, which in the era of the neoliberal economic concept brought the area of media and business into a mere self-sustainability, and in many cases a complete collapse in the free market of goods and capital. A survey of Birodi (2013) conducted on a representative sample of 3,200 respondents on media literacy in Serbia, high school students, civic education professors, students of journalism, journalists showed the following: There is a false impression of the level of media literacy among respondents. That is why education on the general media literacy of all actors is necessary, and education on new media and social networks is especially important. Raising awareness about the power of

$10 \quad$ UNS (2014), www.uns.org.rs

Vol. 17, № 1, 2020: 143-154 
consumers is necessary - all researchers said that the media does not have quality, but also that they have no impression that they can do something about it. Media as content producers must be involved in media literacy education. The research has shown that high school students use the Internet and social networks more than any other media. Young people also say that they can recognize media manipulation and the media's influence on their environment, but they also state that they are themselves immune to such influences (which is why one task of the Media Literacy Campaign is to indicate them once again to consider the actual level their immunity). One of the worrying conclusions of the research is that students are not completely convinced that they should participate, or they do not want to participate in workshops on the role of the media at all. When it comes to professors of civic education, it was striking that they were not interested in participating in the research.

\section{Profit as a Justification for Sensationalism}

If, however, we penetrate into the essence of media literacy - excluding for a moment the factor of exploitation of technologically available possibilities - we will notice that media literacy is not characterized by the engagement of those who are directly interested in its prosperity and affirmation. It sounds illogical, but recipients do not learn enough about the importance of knowing the legitimacy foundation on which the media stand and do business, although they have to do it on the basis of legal norms and moral principles, which are easily rejected. The whole process in this sense is reduced to the necessary extent, some kind of minimalism and sufficiency to operate functionally economically and logically at that level, make profit, regardless of the price too high precisely because of such business philosophy. Thus, a new paradigm has emerged that commercial effects and moral discourse almost never meet at one point: sensationalism is more desirable than objectivity, tabloidization and accurate information do not come from the same echelon of journalistic outlets, concentration of content is not in the foreground. The form has taken on the primacy, strong enough, to support and strongly incite ignorance and the eclectic state of general illiteracy, vulgarity, pseudo-events, lies and manipulation. The lack of different social media strategies, isolationism and open ignoring practical experiences of the concept of media literacy - defined at the 1992 National Leadership Conference on Media Literacy as the ability to access, analyze, evaluate and send messages via the media - is just one set that makers of media policy in Serbia use as a labyrinth for manipulating and creating social realities according to their own interests and proclaimed goals. Pacification and complete restraint on the openness of two-way communication has reached a situation of general misunderstanding. Recipients confused by the quantity, scope and lack of accurate 
information, more precisely, the abundance of daily disinformation and total elimination of basic theoretical knowledge in the production of media products, are not in a desirable place. Message senders, selected by measure of ignorance, party membership, open corruption, nepotism, create a simulacrum, a false picture of everything that makes life meaningful.

"Media literacy comprehended as functional, covers the broad field of human existence starting from mastering the elemental ability of recognizing and interpreting visual symbols, advertising messages, through the ability to read and fill diagrams and patterns to much higher levels, such as the use of a computer for obtaining information, understanding the relationship signs and meanings, intentions and messages, an emotional and cognitive response to the media announced"11. The claim that the media are neither harmful nor useful, and that they can be both, has long been left unquestioned in Serbian media practice. It is persistent because of the multi-century mantra claiming it untouchable, at the same time protected, by no means other than the uneducated profile that has long created media policy in proportion to the level of education that is frustrating to the extent of intolerance.

\section{Conclusion}

Cultural imperialism, supported by media megasystems, primarily from the United States, imposes global culture in the market and commercial terms. Cultivating traditional values has proven to be a big and complex job, because (media) cultural policy does not encourage meaningful systemic promotion of creativity. Consumer entertainment industry (primarily) suppresses and marginalizes authentic, creative cultural practices, substituting them with pseudocultural content. Entertaining contents (reality programs, various music competitions and sterile infotainment) anesthetized audiences focus on consumerism, consumption culture.

It seems that after all the evidence, the creators of the media scene in Serbia do not have too much need to educate the public and consumers, due to the optimization of technical conditions which in themselves pressure users to overcome them, accept, and eventually buy what is offered. Information as a commodity with value and usable value, in abundance and transmission speed, is a kind of a new doctrine. It offers abundantly everything that is served from certain centers of power, and not on the basis of the full application of theoretical knowledge that would, through the passage of time, literate the users, raise the critical level of consciousness. Understand the reality through pure optics, and not as an imposed model, concentration of power, ownership suspicious structures, inter-

11 Knežević, N. (2008) Časopis za upravljanje komuniciranjem, Fakultet političkih nauka, Beograd, p. 85. 
est spheres, or the neutralization of awareness and understanding of the phenomena and tendencies in which society has existed for years, blurring the entire Serbian media scene. The well-known fact that media literacy in a permanent and unbreakable symbiosis with an extremely high percentage of illiteracy or a very low percentage of functional literacy in society would require the mobilization of relevant state factors in order to eliminate the monstrosity of illiteracy and reduce it to a measure of tolerance.

\section{Literature}

- Amabile, T. M., R. Conti, H. Coon, J. Lazenby, and M. Herron. "Assessing the Work Environment for Creativity", Academy of Management Journal 39, no. 5 (October 1996): 1154-1184.

- Baron Robert (1995): Behaviour in Organizations, Prentice Hall, Inc.

- BIRODI (2013): Istraživanje: Medijska pismenost u Srbiji, Beograd, retrieved from www.birodi.rs

- Castells, M. (2000): Informacijsko doba: Ekonomija, društvo i kultura, Svezak I: Uspon umreženog društva. Zagreb: Golden marketing.

- Castells, M. (2002): Informacijsko doba: Ekonomija, društvo i kultura, Svezak II: Moć identiteta. Zagreb: Golden marketing.

- Castells, M. (2003): Informacijsko doba: Ekonomija, društvo i kultura, Svezak III: Kraj tisućljeća. Zagreb: Golden marketing.

- Department for Culture, Media and Sport (1997) Retrieved from http:// www.culture.gov.uk/about_us/culture/default.aspx.

- Giles, J. (2005): Internet encyclopaedias go head to head. Nature, 438, 900901.

- Jandrić, P. (2015): Digitalno učenje. Zagreb: Školske novine i Tehničko veleučilište u Zagrebu.

- Knežević, N. (2008): Časopis za upravljanje komuniciranjem, Fakultet političkih nauka, Beograd

- Media literacy (1992): a report of the National Leadership Conference on Media Literacy, the Aspen Institute Wye Center, Queenstown Maryland

- Miletić, M., Miletić, N., (2012): Komunikološki leksikon, Beograd, Megatrend univerzitet.

- Milivojević, T. (2011), Psihologija stvaralštva, Beograd, Megatrend univerzitet.

- Novinari bez diploma, Izvor: Politika, 19.01.2006; Strana: A9.

- Peters, M. A. \& Heraud. R. (2015): Toward A Political Theory Of Social Innovation: Collective intelligence and the co-creation of social goods. Journal of Self-Governance and Management Economics, 3(3), 7-23.

- $\quad$ Rheingold, H. \& Jandrić, P. (2015): Learning in the age of mind amplification. Knowledge Cultures, 3(5), 149-164. 
- Rheingold, H. (1995): The Virtual Community: Homesteading on the Electronic Frontier. Cambridge, MA: MIT Press.

- Šikić, T. (2016): Hrvatski obrazovani portal Zbornica, retrieved from https://zbornica.com/index.php?option=com_zoo\&task=item\&item _ $\mathrm{id}=250 \&$ Itemid $=108$

- UNESCO (1982): Grunwald Declaration on media education, Retrieved from www.unesco.org/education/pdf/MEDIA_E.PDF.

- UNS (2014), www.uns.org.rs.

- www.novosti.rs. 
Pregledni naučni članak Primljen 11.07.2018. Odobren 06.11.2018.

\section{MEDIJSKO OBRAZOVANJE KAO PROTIVTEŽA DEVASTACIJI JAVNOG INFORMISANJA U SRBIJI}

U savremenom informatičkom i informacionom društvu kreativnost je uzdignuta na pijedestal, kao uslov za tržišni uspeh, ali i opstanak. Drugim rečima, u postindustrijskoj proizvodnji, dakle celokupnoj ekonomiji, a svakako i medijskim kućama koje naravno posluju po tržišnim principima i temelje se na informacijama, kreativnost je najtraženija roba.

U savremenom društvu znanja, došlo je do snažne afirmacije fenomena kulturnih, odnosno, kreativnih industrija koje imaju veliki značaj za ekonomski, socijalni, politički i opšti razvoj društva. Istovremeno, promene u ekonomskoj, tehnološkoj i kulturnoj sferi snažno su uticale na promene u medijskoj, kao važnoj kreativnoj, ali ipak industriji. To znači da medijski proizvodi (informacija, video, klip) $i$ mediji jesu industrija, ne samo zbog kriterijuma rejtinga, koji diktiraju pravce poslovanja, već $i$ zato što se radi, kao u svakoj industriji, o masovnoj proizvodnji i konzumentima. Kreativnost jeste važan strateški resurs za povećanje konkurentnosti u ekonomiji zasnovanoj na znanju. Ipak, medijska politika ne podstiče sistemsku promociju kreativnosti. Konzumeristička industrija zabave potiskuje i marginalizuje autentične, kreativne kulturne prakse, zamenjujući ih pseudokulturnim sadržajima.

Integrisanje teoretskog znanja i obrazovanja u srpsku medijsku sferu, praktično se nalazi na nultoj tački sa recidivima koji ozbilino dovode u pitanje sveopšti razvoj, primenu znanja savremenih tehnoloških dostignuća, afirmaciju demokratičnosti i slobode kao osnovnog preduslova za sveopšti prosperitet društva.

Ključne reči: Kreativnost, konkurencija, medijsko obrazovanje, medijska industrija, javno informisanje 